5 Stoop J W, Eijsvoogel V P, Zegers B J M, et al. Selective severe cellular immunodeficiency: effect of thymus transplantation and transfer factor administration. Clin Immunol Immunopathol 1976; 6: 289-98.

6 Spector B D, Perry G S, Good R A, Kersey J H. Immunodeficiency diseases and malignancy. In: Twomey $\mathrm{J} J$, Good R A, eds. The immunopathology of lymphoreticular neoplasms. London: Plenum, 1978: 203-22.

$?$ Purtilo D T, Szymanski I, Bhawan J, et al. Epstein-Barr virus infections in the $\mathrm{X}$-linked recessive lymphoproliferative syndrome. Lancet 1978; i: 798-801.
8 Stoop J W, Zegers B J M, Hendrickx G F M, et al. Purine nucleoside phosphorylase deficiency associated with selective cellular immunodeficiency. $N$ Engl J Med 1977; 296: 651-5.

Correspondence to Dr Alan R Watson, Department of Child Health, Royal Manchester Children's Hospital, Pendlebury, Manchester M27 1HA.

Received 11 August 1980

\title{
Transient neonatal hyperparathyroidism secondary to maternal pseudohypoparathyroidism
}

\author{
E J GLASS AND D G D BARR \\ Department of Child Life and Health, University of Edinburgh, and Simpson Memorial Maternity Pavilion, \\ Edinburgh
}

SUMMARY A neonate was found to have normocalcaemic hyperparathyroidism with bone disease. The plasma parathyroid hormone concentration returned to normal by 4 weeks, and healing of the bone lesions was evident by age 5 months. The mother proved to have pseudohypoparathyroidism, previously unsuspected.

Several cases of transient neonatal hyperparathyroidism secondary to untreated maternal hypoparathyroidism during pregnancy have been reported. ${ }^{1-6}$ An association between maternal pseudohypoparathyroidism and hyperparathyroidism in the fetus and newborn infant has not previously been recorded.
We describe an infant with transient neonatal hyperparathyroidism and severe skeletal changes radiologically. The mother was subsequently shown to have pseudohypoparathyroidism.

\section{Case report}

A girl was delivered by elective lower-segment caesarean section for breech presentation at term to a primigravid mother. Birthweight was $2.8 \mathrm{~kg}$. On initial examination bowing of both femora was noted and the hips were thought to be unstable. $X$-ray films showed extensive bony changes (Fig. 1a). Gross demineralisation of the skeleton was evident. Metaphyseal fractures of humeri, femora, and tibiae were present in addition to multiple rib fractures.

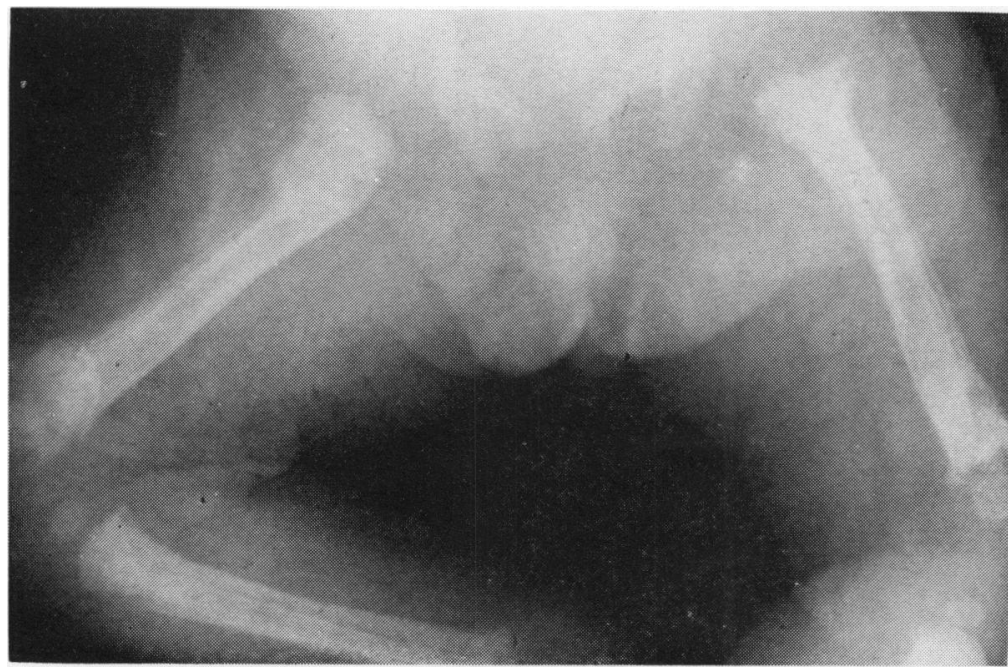

Fig. 1a Changes of hyperparathyroidism at age 1 week. $X$-ray film of femora, showing demineralisation of cortex, periosteal reactions along both shafts, and multiple metaphyseal fractures. 
Extensive subperiosteal new bone formation was noted too.

Biochemical investigations at age 1 week were: plasma calcium $2 \cdot 31 \mathrm{mmol} / 1(9 \cdot 24 \mathrm{mg} / 100 \mathrm{ml})$ (normal 2.05-3.05 mmol/l), phosphate $1.38 \mathrm{mmol} / \mathrm{l}$ $(4.27 \mathrm{mg} / 100 \mathrm{ml}$ ) (normal $1.6-2.9 \mathrm{mmol} / \mathrm{l})$, magnesium $0.72 \mathrm{mmol} / 1(1.75 \mathrm{mg} / 100 \mathrm{ml}$ ) (normal $0 \cdot 6-1.0 \mathrm{mmol} / \mathrm{l})$, alkaline phosphatase $415 \mathrm{IU} / \mathrm{l}$ (normal 70-280), albumin $41 \mathrm{~g} / 1(4 \cdot 1 \mathrm{~g} / 100 \mathrm{ml}$ ), and creatinine $42 \mu \mathrm{mol} / \mathrm{l}(0.47 \mathrm{mg} / 100 \mathrm{ml})$. Serum parathyroid hormone level was high $(2 \cdot 2 \mu \mathrm{g} / \mathrm{l}$, normal $<0.6 \mu \mathrm{g} / \mathrm{l})$, calcitonin was normal $(<24 \mathrm{ng} / \mathrm{l}$, normal $<60 \mathrm{ng} / \mathrm{l})$, and 25-hydroxycholecalciferol value was low $(4 \cdot 8 \mathrm{ng} / \mathrm{ml} ; 12.0 \mathrm{nmol} / \mathrm{l}$ (normal 8-15 $\mathrm{ng} / \mathrm{ml} ;>20 \mathrm{nmol} / \mathrm{l})$ ).

Sequential biochemistry confirmed that plasma calcium remained within normal limits. Plasma phosphate rose from the initial low value of 1.38 $\mathrm{mmol} / \mathrm{l}$ to $1.90 \mathrm{mmol} / \mathrm{l}(5 \cdot 88 \mathrm{mg} / 100 \mathrm{ml})$, within the normal range. Alkaline phosphatase, predominantly of bony origin, rose to a maximum of $2667 \mathrm{IU} / \mathrm{l}$ at age 4 weeks and had fallen to $567 \mathrm{IU} / 1$ by 5 months. Parathyroid hormone value fell to $0.53 \mu \mathrm{g} / \mathrm{l}$ at one month and remained normal thereafter. The sequential biochemical findings were associated with radiological improvement. Increase in bone density and pronounced callus formation were evident by the fourth week, and there was resolution of the bone lesions by age 5 months (Fig. 1b). Throughout this period the infant was bottle fed and received vitamin supplementation, including $400 \mathrm{IU}$ vitamin $\mathrm{D}$, daily.

\section{The mother}

She was aged 22 years, and had been diagnosed as epileptic 9 years earıer after several episodes associated with abnormal movements, some of which had resulted in an altered level of consciousness. Electroencephalogram and skull $x$-ray films performed then had apparently been normal. Since then she had been maintained on anticonvulsant therapy with phenobarbitone $30 \mathrm{mg}$ three times daily and phenytoin $100 \mathrm{mg}$ twice daily, this treatment being continued throughout pregnancy.

On examination she was obese and short $(4 \mathrm{ft} 11$ in tall), with a round face. She had no skeletal anomalies and none of the skin, hair, or nail changes of chronic hypoparathyroidism. Recurrent moniliasis had not been a problem. Biochemical results one week after delivery included plasma calcium $1.86 \mathrm{mmol} / \mathrm{l}$ $(7 \cdot 44 \mathrm{mg} / 100 \mathrm{ml}$ ) (normal $2 \cdot 10-2 \cdot 70 \mathrm{mmol} / \mathrm{l}$ ), phosphate $1.40 \mathrm{mmol} / \mathrm{l}(4.3 \mathrm{mg} / 100 \mathrm{ml}$ ) (normal 0.8-1.40 mmol/l), alkaline phosphatase $117 \mathrm{IU} / \mathrm{l}$ (normal 50-250), creatinine $62 \mu \mathrm{mol} / 1(0.70 \mathrm{mg} /$ $100 \mathrm{ml})$, and albumin $42 \mathrm{~g} / \mathrm{l}(4 \cdot 2 \mathrm{~g} / 100 \mathrm{ml})$.

During the next months, the plasma calcium level fell to about $1.45 \mathrm{mmol} / 1(5.8 \mathrm{mg} / 100 \mathrm{ml})$ and remained there and the phosphate level rose to $1.99 \mathrm{mmol} / 1(6.2 \mathrm{mg} / 100 \mathrm{ml})$. Three weeks after delivery her serum parathyroid hormone value was $1.0 \mu \mathrm{g} / \mathrm{l}$ (normal $<0 \cdot 6$ ), calcitonin $24 \mathrm{ng} / \mathrm{l}$ (normal $<60$ ), and 25-hydroxycholecalciferol $6.2 \mathrm{ng} / \mathrm{ml}$; $15 \cdot 5 \mathrm{nmol} / 1$ (normal $10-20 \mathrm{ng} / \mathrm{ml} ;>20 \mathrm{nmol} / \mathrm{l}$ ). Skull $x$-ray films showed extensive basal ganglia calcification, confirmed on computerised tomography scan. A dental view showed loss of the normal lamina dura. $X$-ray films of the hands were normal. A parathyroid hormone stimulation test was performed, based on the method of Tomlinson et al. ${ }^{7}$ After the intravenous injection

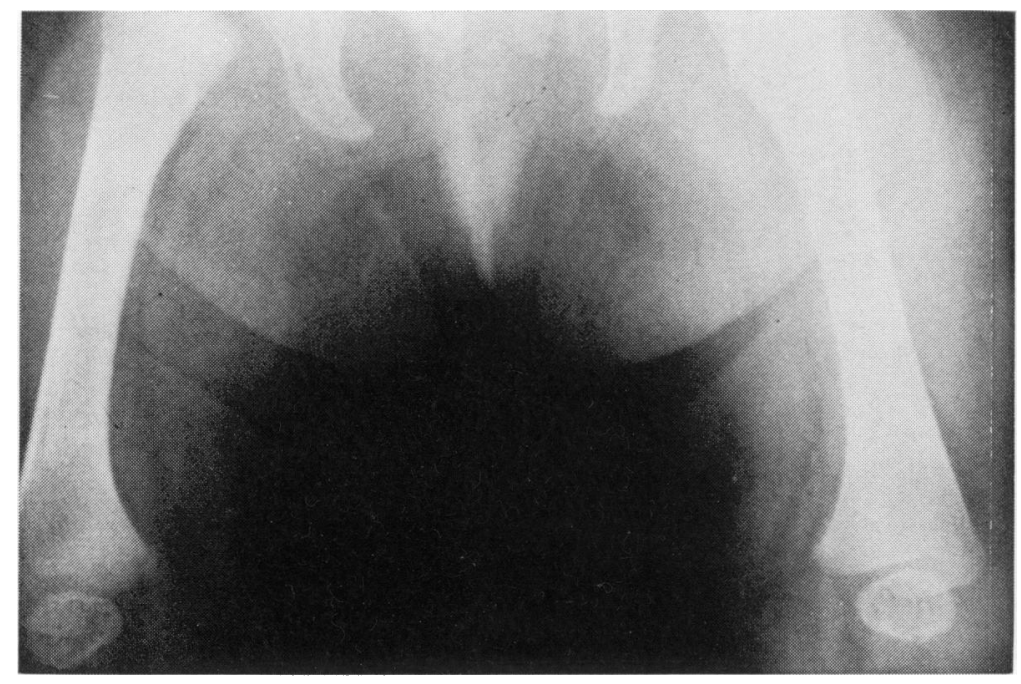

Fig. 1b Resolution at 5 months. 
of $200 \mathrm{IU}$ bovine parathyroid hormone no increase over basal plasma cyclic AMP values (19-21 nmol/l) were shown in the patient, whereas the control plasma cyclic AMP value rose from $10-14$ to 310 $\mathrm{nmol} / 115$ minutes after administration. In addition, urinary phosphate excretion was augmented in the control subject, but not in the patient. Treatment has now been started with 1- $\alpha$-hydroxycholecalciferol and has resulted in a rise in plasma calcium to $1.97 \mathrm{mmol} / \mathrm{l}(7.88 \mathrm{mg} / 100 \mathrm{ml})$ and a fall in plasma phosphate to $1.50 \mathrm{mmol} / \mathrm{l}(4.7 \mathrm{mg} / 100 \mathrm{ml})$. Serum parathyroid hormone has remained persistently high, in the range 0.66 to $0.95 \mu \mathrm{g} / \mathrm{l}$.

\section{Discussion}

This infant was found to have diffuse metabolic bone disease and the diagnosis of neonatal hyperparathyroidism was made on the basis of an increased plasma parathyroid hormone concentration in association with radiological changes. The transient nature of the condition was shown by resolution of the bony lesions at 5 months and by the return of the parathyroid hormone concentration to normal by age 4 weeks.

In the mother, who had normal renal function, the findings of persisting hypocalcaemia and hyperphosphataemia strongly suggested hypoparathyroidism, and this was supported by the presence of basal ganglia calcification. However, she exhibited some phenotypic features of pseudohypoparathyroidism and the persisting high parathyroid hormone values were inconsistent with a diagnosis of idiopathic hypoparathyroidism. The negative cyclic AMP response to exogenous parathyroid hormone confirmed the diagnosis of pseudohypoparathyroidism. Loss of the normal lamina dura is a radiological finding that tends to be associated with osteomalacia, osteoporosis, and hyperparathyroid bone disease. It is known that some patients with pseudohypoparathyroidism have isolated bone responsiveness producing evidence of hyperparathyroid bone disease. In this woman there was no other evidence of hyperparathyroid bone disease and and in particular the $x$-ray films of her hands were normal. Osteomalacia has to be considered in view of the previous anticonvulsant therapy and low maternal plasma 25-hydroxycholecalciferol concentration. Poor levels of vitamin D in the mother might have been responsible for the low level of vitamin $D$ in the infant as shown by low plasma 25-hydroxycholecalciferol concentrations.

In a previous case of transient neonatal hyperparathyroidism, ${ }^{5}$ although radiological healing was achieved with 600 IU vitamin D daily, the parathyroid hormone value was still raised at 6 weeks, and the infant's plasma 25-hydroxyvitamin D level remained low. After a single dose of $15 \mathrm{mg}$ vitamin D the parathyroid hormone level fell to normal. It was suggested that neonatal hyperparathyroidism led to increased vitamin $D$ requirements producing vitamin D deficiency which, in turn, potentiated the hyperparathyroidism in this patient.

In our patient satisfactory 25-hydroxycholecalciferol concentrations $(18 \cdot 1$ and $25.6 \mathrm{ng} / \mathrm{ml} ; 45 \cdot 3$ and $64.0 \mathrm{nmol} / \mathrm{l}$ ) were achieved with $400 \mathrm{IU}$ supplemental vitamin $\mathbf{D}$ daily, and the parathyroid hormone value had fallen to within normal limits within 4 weeks.

Neonatal hyperparathyroidism secondary to maternal hypoparathyroidism has been described in several previous cases. ${ }^{1-6}$ The maternal disorder has been idiopathic or post-thyroidectomy in nature. In each case the disorder has been undiagnosed or was poorly controlled during pregnancy, and uncontrolled maternal hypoparathyroidism resulting in persisting intrauterine hypocalcaemia is considered to be the stimulus to increased production of parathyroid hormone in the fetus. Parathyroid hyperplasia has been confirmed at necropsy in infants who have died in the neonatal period. Neonatal plasma calcium values have varied, some being high or, as in our case, some being normal. Bony changes were evident in 6 of 8 cases demonstrated either radiologically or at necropsy. In the babies who survived the immediate newborn period, radiological healing occurred between 4 and 7 months, and this was the case in our patient. The index case died at age 2 months from pneumonia, having had persisting hypercalcaemia and failure to thrive. Our patient remains generally well, but is gaining weight slowly.

In infants with diffuse bone changes consistent with metabolic bone disease, with or without abnormal biochemistry, the possibility of chronic hypocalcaemia in the mother should be investigated.

\section{References}

1 Gerlóczy F, Farkas K. Hyperparathyroidism in newborn - mother with chronic hypoparathyroidism (in Russian). Acta Med Acad Sci Hung 1953; 4: 73-85.

2 Aceto T, Jr, Batt R E, Bruck E, Schultz R B, Perez Y R. Intrauterine hyperparathyroidism: a complication of untreated maternal hypoparathyroidism. J Clin Endocrinol Metab 1966; 26: 487-92.

3 Bronsky D, Kiamko R T, Moncada R, Rosenthal I M. Intrauterine hyperparathyroidism secondary to maternal hypoparathyroidism. Pediatrics 1968; 42: 606-13.

4 Landing B H, Kamoshita S. Congenital hyperparathyroidism secondary to maternal hypoparathyroidism. J Pediatr 1970; 77 : 842-7.

5 Sann L, David L, Thomas A, Frederich A, Chapuy M C, François R. Congenital hyperparathyroidism and vitamin $D$ deficiency secondary to maternal hypoparathyroidism. Acta Paediatr Scand 1976; 65 ; 381-5. 
${ }^{6}$ Goldberg E, Winter S T, Better O S, Berger A. Transient neonatal hyperparathyroidism associated with maternal hypoparathyroidism. Isr J Med Sci 1976; 12: 199-201.

7 Tomlinson S, Hendy G N, O'Riordan J L H. A simplified assessment of response to parathyroid hormone in hypoparathyroid patients. Lancet 1976; i: 62-4.
Correspondence to Dr E J Glass, Paediatric Department, Simpson Memorial Maternity Pavilion, Lauriston Place, Edinburgh EH3 9EF.

Received 15 July 1980

\title{
Effects of water supplementation on physiological jaundice in breast-fed babies
}

\author{
MANOEL DE CARVALHO, MICHAEL HALL, AND DAVID HARVEY
}

Queen Charlotte's Maternity Hospital, London

SUMMARY The effect of water supplementation in normal, term, breast-fed babies with physiological jaundice was studied. Water supplementation was given to 120 babies and 55 received no extra fluids. There was no significant difference between the two groups when peak serum bilirubin levels and incidence of phototherapy were compared.

Although there is conflicting evidence about the incidence of hyperbilirubinaemia in bottle- and breast-fed newborn infants, recent reports support the view that jaundice occurs more often, and with relatively higher serum bilirubin concentrations, in

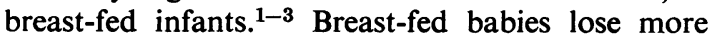
weight in the first few days of life and, in the past, this was thought to be related to the presence of jaundice. ${ }^{4}$ It is therefore common to give water supplements to breast-fed babies in an attempt to reduce the severity of jaundice. However, the use of water supplements may interfere with both the establishment and duration of breast-feeding. ${ }^{5}$ The present study was undertaken to determine the effect of water supplementation on the course of physiological jaundice in breast-fed babies.

\section{Patients and methods}

Between 1 June and 31 November 1979 infants in the postnatal wards at this hospital were placed in one of two groups. In group $1(n=55$, one ward) breast-fed babies received no fluid supplementation from birth, and in group $2(n=120$, three wards) water supplementation was given ad libitum at the end of each breast feed. All babies were fed on demand and received the first feed within 3 hours of birth. Only normal term babies whose birthweight was $2.5 \mathrm{~kg}$ or more were included.
Babies who were considered to have physiological jaundice entered the study if the serum bilirubin concentration reached $200 \mu \mathrm{mol} / \mathrm{l}(11.7 \mathrm{mg} / 100 \mathrm{ml})$. Phototherapy was started at a serum bilirubin level of $320 \mu \mathrm{mol} / 1(18.7 \mathrm{mg} / 100 \mathrm{ml})$. Any baby with rhesus disease, hypothyroidism, or congenital infection was excluded. Any baby with a definite diagnosis of $\mathrm{ABO}$ haemolytic disease was excluded, but it is possible that a few babies with very mild disease were included because of the difficulty in making the diagnosis.

All blood specimens were taken daily by heelprick and the serum bilirubin concentration was measured using an American optical bilirubinometer. ${ }^{6}$

There was no significant difference between the groups for number of deliveries by forceps, caesarean section, or ventous extraction. There were 8 breech deliveries in group 2 and none in group 1.

\section{Results}

As can be seen from the Table, there was no

Table Data $(S D)$ for the two groups of infants

\begin{tabular}{|c|c|c|c|}
\hline & $\begin{array}{l}\text { Group } I(n=55) \\
\text { (no supplement) }\end{array}$ & $\begin{array}{l}\text { Group } 2(n=120) \\
\text { (water } \\
\text { supplement) }\end{array}$ & $\begin{array}{l}\text { Significance } \\
\text { of different } \\
\text { incidence }\end{array}$ \\
\hline $\begin{array}{l}\text { Mean birthweight (g) } \\
\text { Mean lowest }\end{array}$ & 3249 (397) & $3372(411)$ & NS* \\
\hline $\begin{array}{l}\text { weight (g) } \\
\text { Mean weight }\end{array}$ & 3034 (386) & $3181(396)$ & $\mathrm{P}<0.05$ \\
\hline $\begin{array}{l}\text { loss (g) } \\
\text { Mean peak serum }\end{array}$ & 215 (116) & $191(91)$ & $\mathrm{NS}^{*}$ \\
\hline bilirubin $(\mu \mathrm{mol} / \mathrm{l})$ & $263 \cdot 5$ & 260 & NS \\
\hline $\begin{array}{l}\text { peak bilirubin (days) } \\
\text { Number receiving }\end{array}$ & $4 \cdot 62$ & $4 \cdot 64$ & NS \\
\hline photother & 8 & 11 & $\mathbf{N S}+$ \\
\hline
\end{tabular}

Conversion: SI to traditional units-bilirubin: $1 \mu \mathrm{mol} / 1 \approx 0.058$ $\mathrm{mg} / 100 \mathrm{ml}$.

*Student's $t$ test, $\dagger \chi^{2}, \mathrm{NS}=$ not significant. 